\title{
A POLÍTICA PÚBLICA PREVIDENCIÁRIA E A FUNAI: O ACESSO AOS BENEFÍCIOS PELOS SEGURADOS ESPECIAIS INDÍGENAS NOS MUNICÍPIOS DE PORTO SEGURO E EUNÁPOLIS/BA
}

\author{
AUTOR: RENILDO NERES CERQUEIRA \\ CO-AUTOR/ORIENTADOR: DANIELA ROCHA TEIXEIRA
}

\begin{abstract}
Resumo: A Constituição Federal de 1988, em seu artigo 195, §8, prevê a forma de contribuição diferenciada para o segurado que trabalha em regime de economia familiar; surgindo daí a figura do segurado especial. Na Ação Civil Pública no 2008.71.00.024546-2/RS, ajuizada pelo Ministério Público Federal-MPF, a Fundação Nacional do Índio (FUNAI) foi instada a fornecer certidão que comprove a situação de indígena-artesão e que o Instituto Nacional de Seguridade Social (INSS) a admitisse e classificasse na categoria de segurado especial, para fins de concessão de benefícios previdenciários. No intuito de se aprofundar nessa temática, o projeto de pesquisa, ora intitulado "A política pública previdenciária e a FUNAI: o acesso aos benefícios pelos segurados especiais indígenas no município de Porto Seguro/BA e Eunápolis/BA", é um dos quatro eixos temáticos de investigação em estudos de Direito Previdenciário que se realiza para saber as condições de acesso aos benefícios pelos segurados especiais indígenas de Porto Seguro/BA e Eunápolis/BA, tendo como escopo analisar a efetividade das normas brasileiras de direito previdenciário como política pública de concessão de benefícios a esses segurados especiais. A metodologia restringiu-se a ser de base qualitativa, de cunho bibliográfico, explorando conhecimentos no âmbito dogmático, doutrinário e jurisprudencial do Direito Previdenciário. Nesse alcance discute-se os pontos de inflexão entre a norma e a política previdenciária indigenista, na tentativa de descortinar qual o nível de acesso aos benefícios pelos segurados especiais indígenas nos Municípios de Porto Seguro e Eunápolis. A abordagem do presente trabalho se deu introdutoriamente fazendo menção as normas constitucionais que fundamentam o direito do segurado especial indígena, por conseguinte, na colheita dos resultados, entendemos através da literatura específica que o segurado especial indígena não é, exclusivamente, aquele que se encontra aldeado, inclui-se também os que estão em área urbana e que sobrevivem do ofício de artesão em regime de economia familiar. Conclui-se com a percepção de que os segurados especiais indígenas têm limitações, por diversos fatores, ao usufruto dos direitos previdenciários talhados na Constituição de 88 , incluindo a falta de formalidade no preenchimento da certidão para comprovação de segurado especial indígena.
\end{abstract}

Palavras-chave: Direito previdenciário, Segurado especial indígena. 